\title{
Wear and Corrosion of Cast Al Alloy Piston with and without Brake Oil
}

\author{
Olawale Olarewaju Ajibola ${ }^{1,2}$ and Daniel Toyin Oloruntoba ${ }^{1}$ \\ ${ }^{1}$ Metallurgical and Materials Engineering Department, Federal University of Technology, Akure, Akure 340252, Nigeria \\ ${ }^{2}$ Materials and Metallurgical Engineering Department, Federal University Oye Ekiti, Oye Ekiti 371104, Nigeria
}

Correspondence should be addressed to Olawale Olarewaju Ajibola; olawale.ajibola@fuoye.edu.ng

Received 26 May 2015; Revised 2 September 2015; Accepted 13 September 2015

Academic Editor: Pradeep Lancy Menezes

Copyright (C) 2015 O. O. Ajibola and D. T. Oloruntoba. This is an open access article distributed under the Creative Commons Attribution License, which permits unrestricted use, distribution, and reproduction in any medium, provided the original work is properly cited.

\begin{abstract}
The effects of wear and corrosion of cast AA6061 aluminium alloy were studied with and without brake fluid using a wear jig while the corrosion rate was determined in brake fluid for 70 days under two experimental set-ups. The tests, yielded $0.00000123 \mathrm{~g} / \mathrm{mm}^{2} / \mathrm{min}$ highest wear rate at 147000 wear cycles and $0.0334 \mathrm{mg} / \mathrm{mm}^{2} / \mathrm{yr}$ as the highest corrosion rate within the early 39th day of immersion in oil, the values being considered comparatively lower than those obtained for Al alloy in most common wet abrasion test and corrosion in aqueous solutions as previously reported in literature. The material loss rates to wear and corrosion were determined from the equations relating to wear and corrosion based on the ASTM designations. The results show that the combined actions of wear and corrosion contribute to the total loss of piston material immersed in brake oil. This is greater than either of their effects individually on cast $\mathrm{Al}$ alloy in the brake oil.
\end{abstract}

\section{Introduction}

Corrosion involves chemical or electrochemical reactions of the material while wear is a mechanical material degradation process occurring on rubbing or impacting surfaces [1-3]. Corrosion may speed up wear and vice versa [4]. Tribology studies friction, wear, and lubrication whereas corrosion involves the chemical and electrochemical reactions between an object (usually a metal) and its surroundings. The problems originating from wear and corrosion could be prevented or alleviated by process and materials design, deposition, and surface treatment methods [5].

There can be corrosion hastened wear or wear accelerated corrosion. Both of these observable facts, as well as fretting corrosion, are in the larger class of tribocorrosion. Tribocorrosion is a material deterioration process due to the combination of corrosion and wear effects [6].

Aluminium recycling industry is gaining large ground in automotive and automobile applications, of which the replacement of worn out pistons used in the hydraulic brake master cylinder with cast aluminium alloy is popular. Aluminium alloys (AAs) are alloys in which aluminium (Al) is the chief metal. The characteristic alloying elements are $\mathrm{Cu}, \mathrm{Mg}, \mathrm{Mn}, \mathrm{Si}$, and $\mathrm{Zn}$. AAs are widely used in engineering constructions and machineries where light weight and/or corrosion resistance is needed such as automotive engines [7]. Al-Mg alloys are established to be functional in master brake and clutch cylinder and in automotive machine cylinders.

It is fundamental that brake fluids must have certain quality and meet certain standards for the braking system to work appropriately. Pure aluminium and its alloys react with acids, bases, and alkalis being amphoteric in nature. The $\mathrm{pH}$ of brake fluids may range from 10.0 to 11.5 [8], being alkaline, and has strong ability to attack aluminium alloy parts in the brake device. For this reason, sufficient quantity of inhibitor should be blended with the brake oil mixture.

The synergy of significant technical challenges and the high cost directly relating to corrosion provide strong motivations for engineers and other technical workforces to develop a concrete grip on the fundamentals of corrosion [9]. There has been continuous increase in the number of researches performed on reducing the synergy of wear and corrosion on various engineering materials in their environments of usage 
[9-12]. This is aimed at lengthening their service lifetime and dependability.

Diverse equations have been used to relate wear and other properties among which Archard's equation that related wear with hardness has been conventional. Khrushchov $[1,13,14]$ established the relationship with hardness and projected an empirical correlation with elastic modulus as given in

$$
w=\frac{k_{5}}{E^{1.3}}
$$

where $E$ is the elastic modulus.

Evans $[1,15,16]$ worked on wear erosion rate, $E$. The erosion rate, $E$, relates the mass or volume of material removed per unit mass of erodent forced on the surface. It is dependent on power-law velocity as in

$$
E=k V^{n}
$$

where $n$ is a velocity exponent and $k$ is a constant [1].

The most widely known expression is Archard's equation [1] in which the rate of wear (volume per unit of time) is as shown in

$$
\Upsilon=k \frac{L S}{H}
$$

where $S$ is the sliding speed, $H$ is the hardness of the softest materials, $L$ is the applied load, and $k$ is a constant known as the wear coefficient.

Tribocorrosion is not just the sum of the two processes together. Synergistic effects perform a very significant role [17]. Many researches have been carried out in erosioncorrosion which is another type of tribocorrosion process.

Tribocorrosion experiment requires a Tribometer and an Electrochemical Measuring Device. The Tribometer provides the mechanical loading in motion, measures the normal force and the frictional force, and yields the coefficient of friction (COF) with respect to time and materials elimination rate, whereas the Electrochemical Measuring Device determines the voltage and electrical current and the open-circuit potential (OCP), electrochemical impedance, and electrochemical polarization and gives the corrosion current figures $\left(i_{\text {corr }}\right)$ and potential $\left(E_{\text {corr }}\right)$ and the rate of materials removal due to corrosion [18].

The synergism has been strongly utilised in different experiments to quantitatively measure corrosion (chemical, electrochemical), mechanical wear, and wear-corrosion. The combined effects of corrosion, $C$, and wear, $W$, produce total damage rates that are much greater than the summative effects of each route taken alone. This is indicating strong synergism between corrosion and wear. The synergistic component $S_{(C, W)}$ is that fraction of the whole damage that results from the corrosion and wear interactive processes. The total material loss, $T_{(C, W)}$, is related to the synergism by

$$
T_{(C, W)}=W_{0}+C_{0}+S_{(C, W)}
$$

where $W_{0}$ is the wear damage in the absence of corrosion and $C_{0}$ is the corrosion damage in the absence of mechanical wear.
Equation (4) means that mechanical wear and corrosion are interdependent.

For instance, Neville and Hodgkiess [19] reported erosion-corrosion behaviour under slurry conditions using (5) to decide the system of material loss which is caused by mechanical contact and electrochemical process:

$$
\begin{aligned}
& T=E+C+S, \\
& S=E_{c}+C E \\
& T=E+C+E_{c}+C E
\end{aligned}
$$

where $T$ is the total weight loss of the material in erosioncorrosion setting and the wholesome material degradation by erosion is $E$. $C$ is the material loss to electrochemical corrosion only. $S$ is the synergetic component which involves $E_{c}$ (corrosion impact on erosion) and $C E$ (erosion influence on corrosion). In addition, electrochemical experiment and Faraday's Law were applied to find out material loss due to corrosion effect.

The prevailing reasons for failure in the case of brake master cylinder are mechanical wear (due to abrasion by the contacting surfaces of pistons and cylinder wall when oil level is low or dry), corrosion (due to chemical attack of oil, when the cylinder is not engaged), and the combined effect of wear and corrosion, that is, tribocorrosion, (when the master cylinder and piston are engaged in oil). In the previous studies, Ajibola et al. had reported studies on the metallurgical properties and wear of cast AA6061 Al alloy materials [20-24]. In another instance, experimental studies were carried out on the electroless nickel plating as a control measure for AA6061 surface against wear and corrosion in corrosive fluid [25].

Unlike other fluid media (acids, base, salt solutions, agrofluid extracts, and agrochemicals), literature based information is scarcely available on the wear and corrosion of aluminium alloys in brake fluid. Thus, the present study investigates effects of corrosion and wear of cast $\mathrm{Al}$ alloy piston in brake oil under distinct experimental conditions.

\section{Materials}

The materials used for the wear and corrosion tests include the hydraulic fluid sourced from brake oil (DOT 3), cast Al alloy pistons (for wear tests), and cast $\mathrm{Al}$ alloy coins (for corrosion tests).

\section{Method}

3.1. Production of Cast Aluminium Alloy Samples. About $2000 \mathrm{~g}$ of as-received Al scrap was weighed into the melting pot, melted, and held at temperature range of $750 \pm$ $10^{\circ} \mathrm{C}$ in Taifa model electric furnace under a controlled atmosphere. The molten metal was treated with $34 \mathrm{~g}$ of magnesium ferrosilicon (MgFeSi) powder in a procedure similar to cast iron [26] before pouring at temperature of $750 \pm 10^{\circ} \mathrm{C}$ into preheated moulds. It is allowed to solidify and cool to obtain eutectic Al-Si structured phase. The cast samples were removed from the sand mould. Two sets of 


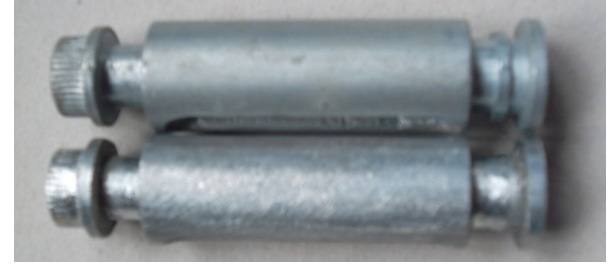

(a)

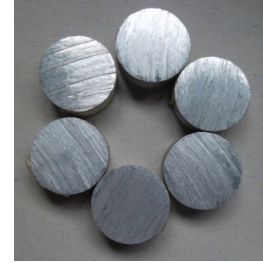

(b)

FIGURE 1: Showing (a) machined cast Al alloy piston specimen for wear tests and (b) coin shape specimen for corrosion tests.

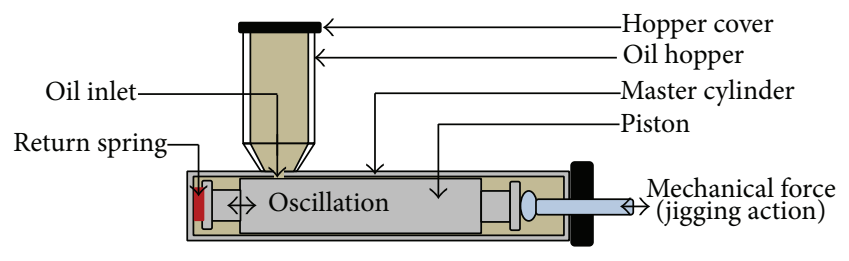

FIGURE 2: Cross section of piston in the wear test jig showing the applied force on the cast piston.

tests specimens in Figures 1(a) and 1(b) were produced: The cast rod was machined to a piston of $100 \mathrm{~mm}$ long by $12 \mathrm{~mm}$ diameter (used for wear tests) while the cast piston was cut to $30 \mathrm{~mm}$ long by $12 \mathrm{~mm}$ diameter (used for corrosion resistance tests). The surfaces of the test samples were grinded and polished with a set of $60 \mu \mathrm{m}, 100 / 120 \mu \mathrm{m}$, $220 \mu \mathrm{m}, 320 \mu \mathrm{m}, 400 \mu \mathrm{m}, 600 \mu \mathrm{m}, 800 \mu \mathrm{m}$, and $1200 \mu \mathrm{m}$ emery paper grits in sequence. Not less than three repeated tests were carried out and readings taken for each of the wear and corrosion tests to obtain highly consistent and reliable results.

3.2. Microstructural Examination of Samples. The microstructure of samples was examined using prepared thin sections under high resolution metallurgical microscope with digital camera (Accu-Scope microscope model). The sections were examined under $\times 800$ magnifications. The surfaces of cast piston and coin shape samples were examined under high resolution microscopic camera (Samsung ST65/HD5X-14.2 model).

3.3. Procedure for Wear Tests. The cast piston is inserted inside brake master cylinder of the wear test jig machine (Figure 2) as described in the previous reports [20, 22, 23]. The machine is electrically powered, causing mechanical force by jigging action on the cast piston. The constant to and fro movement causes the cast piston to wear. The piston oscillates at different revolutions from 1225 to 269500 cycles. The wear cycles were varied by allowing the piston to oscillate for 1 to 220 minutes at 10 -minute interval. The final weight of the specimen was determined by weighing on digital weighing machine after each cycle. The experiment was performed for necessary comparison of the wear rates of cast piston in cylinder with and without brake oil. The wear rate subject to different oscillating periods is calculated from the wear volume $W_{v}$ which was determined from the density $\rho\left(\right.$ in $\left.\mathrm{gcm}^{-3}\right)$ in

$$
V_{w}=\frac{m}{\rho}
$$

where $m$ is the weight loss or wear loss (g). It is the difference between the original weight $W_{i}$ and the final weight $W_{f}$ of the object after wear exposure in

$$
\text { wear loss }\left(W_{l}\right)=W_{f}-W_{i}=\Delta W \text {. }
$$

The wear rate $W_{R}$ was calculated in $\mathrm{g} / \mathrm{cm}^{2} / \mathrm{min}$ as in

$$
\text { wear rate } W_{R}=\frac{W_{v}}{\rho A t} \text {, }
$$

where $W_{v}$ is wear volume loss $\left(\mathrm{cm}^{3}\right), \rho$ is density of alloy $\left(\mathrm{gcm}^{-3}\right), A$ is surface area of wear exposure $\left(\mathrm{cm}^{2}\right)$, and $t$ is tear exposure time (minutes).

Wear loss was determined by measuring either mass change or dimensional change.

From (8), wear volume $W_{v}$ with respect to the change in cross sectional area is given as in

$$
\Delta A \times L=\frac{\rho}{(\Delta M)} \mathrm{mm}^{3},
$$

where $\Delta A$ is change in cross sectional area and $L$ is length of contact surface of specimen.

The maximum volume of wear that can occur is described by Archard's equation [1] in

$$
W_{v}=A d,
$$

where $W_{v}$ is the volume of material removed, $A$ is the surface area of the specimen, and $d$ is the distance slid.

Wear resistance $R_{w}$ is simply defined by [1] as the reciprocal of wear volume $W_{v}\left(\right.$ in $\mathrm{cm}^{-3}$ or $\mathrm{mm}^{-3}$ ) as in

$$
R_{w}=\frac{1}{W_{v}} .
$$

3.4. Determination of Corrosion Rates. The initial weights $\left(M_{1}\right)$ of the cast samples were measured using electric digital weighing machine $(0.0001 \mathrm{~g})$. Samples were fully immersed in the test brake fluid. The specimens were removed from the fluid after stipulated immersion time, rinsed in water, 
TABLE 1: Chemical composition of cast aluminium alloy samples.

\begin{tabular}{lccccccccc}
\hline \multirow{2}{*}{ Piston samples } & Matrix & \multicolumn{3}{c}{ Major elements } & \multicolumn{2}{c}{ Neutral } & \multicolumn{3}{c}{ Microstructure modifier } \\
& $\mathrm{Al}$ & $\mathrm{Si}$ & $\mathrm{Mg}$ & $\mathrm{Cu}$ & $\mathrm{Zn}$ & $\mathrm{Ti}$ & $\mathrm{Mn}$ & $\mathrm{Cr}$ & $\mathrm{Fe}$ \\
\hline Cast Al alloy & 97.432 & 1.293 & 0.598 & 0.202 & 0.001 & 0.051 & 0.051 & 0.041 & 0.331 \\
\hline
\end{tabular}

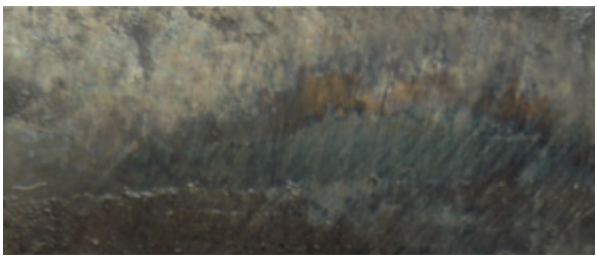

(a)

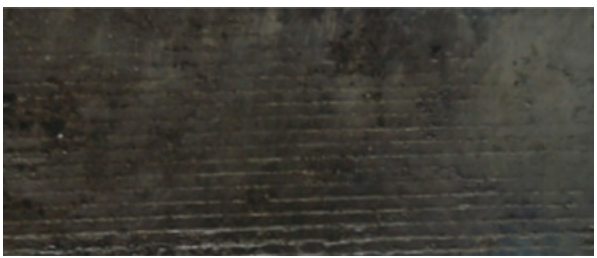

(b)

FIGURE 3: Topography of surface of cast Al alloy piston after wear test in master cylinder (a) with and (b) without oil.

and dried with cotton wool to remove water and other impurities before the final weights $\left(M_{2}\right)$ were determined. The weight loss was determined from the difference between the final weight $\left(M_{2}\right)$ and initial weight $\left(M_{1}\right)$ of the sample before immersion. The cast piston specimens were regularly examined daily for 70 days. The corrosion rate was calculated in mils per year using (12), according to ASTM [27] as reported by Fontana [28]:

$$
\text { corrosion rate }=\frac{K \Delta W}{\rho A t}
$$

where $K=534$ (corrosion rate constant), $\Delta W$ is weight loss (g), $\rho$ is density of the material $\left(\mathrm{g} / \mathrm{cm}^{3}\right), A$ is total area of exposure $\left(\mathrm{cm}^{2}\right)$, and $t$ is exposure time in hours.

The impacts of mechanical wear and corrosive wear on the surface morphology (appearance, colour, and roughness) of the cast piston surfaces were inspected under microscopic camera using Samsung ST65/HD5X-14.2 model, while the characterization of the chemical composition of the corrosion products on the surface of specimen was assessed by SEM technique using the Jeol JSM-7600F SEM with EDX facilities.

\section{Results and Discussion}

4.1. Chemical Compositions of Aluminium Alloy Samples and Brake Fluid. The results of chemical compositions of cast aluminium alloy samples used in this experiment are presented in Table 1, while the chemical properties of hydraulic fluid (brake oil) as supplied by the manufacturer [20] are shown in Table 2, respectively.

4.2. Wear Resistance Tests of Cast Pistons. The result of the hardness tests shows the HBN of 226.49 Mpa for cast Al alloy sample (Table 3 ). The results of the wear tests carried out on the cast aluminium samples are presented graphically as plot of the wear rate and wear resistance against the wear time. The microphotographs showing appearances and wear rates of the surfaces of the cast test specimens after wear test in master cylinder with and without oil are presented in Figures 3-5.
TABLE 2: Chemical properties of hydraulic fluid (brake oil).

\begin{tabular}{lc}
\hline Ingredient name & \% wt. or \% vol. \\
\hline Triethylene glycols & $5-20$ \\
Tetraethylene glycol monobutyl ether & $5-20$ \\
Polyethylene glycol & $5-20$ \\
Diethylene glycols & $5-20$ \\
Polyalkylene glycols & $5-20$ \\
Trade Secret Inhibitor Package & $<3$ \\
pH & $10.0-11.5$ \\
Water solubility & Soluble \\
\hline
\end{tabular}

Source: manufacturer [23].

Figure 3(a) shows the macrophotographs of the surface topography of cast $\mathrm{Al}$ alloy piston with oil after wear test with hydraulic oil. The effect of wear due to friction is not much seen on the physical appearance of the piston. The oil lubricates the system thereby reducing the wear rate of the cast piston. The appearance of the surface examined under the microscope is also characterized by scratches and decolouration of the surface of the piston after a wear time of 220 minutes (about 269500 wear cycles). The wear jig did not cause deep cuttings as it was observed in the case of working the piston without oil (Figure 3(b)).

Figures 3(a) and 3(b) show the macrophotographs of the surface of cast piston with and without oil after wear test without hydraulic oil. It was a dry wear test performed in absence of oil. The effect of friction is more pronounced without oil (Figure 3(b)). The appearance of the surface examined under the microscope shows traces of mild cuttings on the surface of the piston after a wear time of 220 minutes (about 269500 wear cycles). This shows that cast piston wears at lower rate in oil than without oil.

In Figures 4 and 5, some strategic points are selected on the curves for the comparisons. The figure shows that there are regions of no wear, constant wear rate, increase in wear rate, and reduction in wear rate. At the initial stage of the wear tests, there were active periods when no wear was experienced. This initial stage clarifies the time when the 
TABLE 3: Hardness and strength properties of cast piston substrates.

\begin{tabular}{|c|c|c|c|c|c|c|c|}
\hline Samples & $\begin{array}{l}\text { HBN } \\
\text { Pnt } 1\end{array}$ & $\begin{array}{l}\text { HBN } \\
\text { Pnt } 2\end{array}$ & $\begin{array}{l}\text { HBN } \\
\text { Pnt } 3\end{array}$ & $\begin{array}{l}\text { HBN } \\
\text { Pnt } 4\end{array}$ & $\begin{array}{l}\text { Average } \\
\text { HBN }\end{array}$ & $\begin{array}{c}\text { Strength } \\
(\mathrm{MPa})\end{array}$ & $\begin{array}{l}\text { Observation } \\
\text { (porosity, etc.) }\end{array}$ \\
\hline $\begin{array}{l}\text { Cast Al alloy } \\
\text { (CP-TS21) }\end{array}$ & 63.4 & 64.4 & 64.1 & 63.3 & 63.8 & 226.49 & Few pores \\
\hline
\end{tabular}

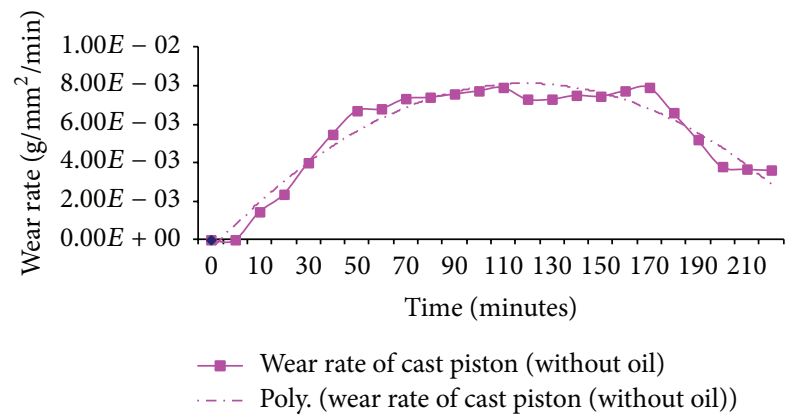

FIgURE 4: Wear rates of cast piston in master cylinder without oil.

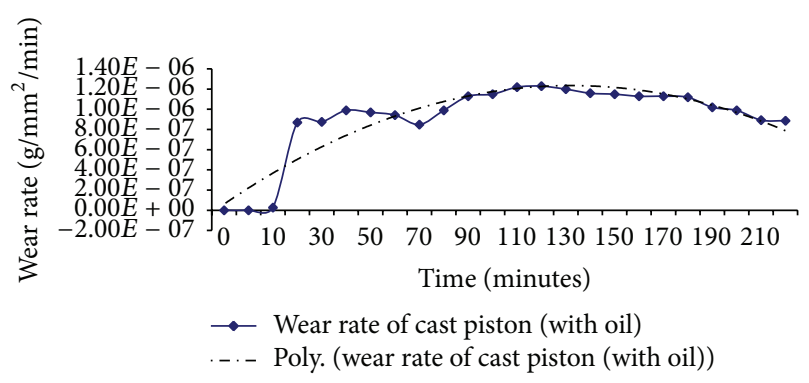

FIGURE 5: Wear rate of cast piston in master cylinder with oil.

piston material is functionally perfect in the automobile. These are for very short periods of 10 minutes for the cast $\mathrm{Al}$ alloy. Within this time, cast $\mathrm{Al}$ alloy has significantly high wear rate of about $8.00 E-07$ to $1.2 E-06\left(\mathrm{mg} / \mathrm{mm}^{2} / \mathrm{min}\right)$ though these values are much lower than those obtained in the cast piston without hydraulic oil in Figure 4. The mathematical model trend equations are derived for the wear rates as in

$$
W_{R}=-6 E-09 x^{2}+2 E-07 x-1 E-07,
$$

where $0 \leq x \leq 70, x$ is wear time and $W_{R}$ is the wear rates of the cast piston with respect to wear time in master cylinder with brake oil.

The trend of the wear resistance of cast $\mathrm{Al}$ alloy surfaces in the cylinder with hydraulic oil is computed from wear volume data generated from Figure 5. The mathematical model equation is derived for the wear resistance as in

$$
R_{w}=13.145 x^{2}-550.03 x+6387.5
$$

where $0 \leq x \leq 70, x$ is wear time and $R_{w}$ is the wear resistance of the cast $\mathrm{Al}$ alloy with respect to wear time in master cylinder with brake oil.
4.3. Corrosion of Test Specimens Immersed in Brake Oil. Corrosion tests were performed on test specimens immersed in brake oil for 70 days. The surfaces of the test specimens examined under microscopic-photo-camera before and after 70 days of immersion in brake oil are presented as microphotographs in Figure 6. The results of corrosion rate determination of aluminium alloy substrate immersed in brake oil by weight loss and electrochemical methods are presented in Figures 7(a)-7(c).

Even though the corrosion appears to be uniform over the surface (Figure 6(a)), it was more severe in outlook (Figure 6(b)) than the corroded surface of the cast piston in air. This occurred despite the enhanced strength and hardness properties of the cast $\mathrm{Al}$ alloy, the sites of precipitation, and entrapment of some of these compound; chiefly the oxides $\left(\mathrm{Al}_{2} \mathrm{Si}_{4} \mathrm{O}_{10}\right.$ and $\left.\mathrm{MgO} \cdot \mathrm{Al}_{2} \mathrm{O}_{3}\right)$ during casting and solidification of the cast Al-Si alloy serve as weak points for the corrosion attack. Corrosion products and surface decolouration were observed and became significant after 49 days or 7 weeks.

The macrophotograph in Figure 6(a) was taken after the immersion in oil for 70 days. It shows layer of corrosion product found or deposited on the cast piston surface. The colouration shows the effect of the Fe ion corrosion in the cast piston in brake oil. The largest amount of tiny pores was observed on the cast $\mathrm{Al}$ alloy surface after cleaning and examined under the microscopic camera (Figure 6(b)).

Figure 7 illustrates the trends of corrosion rates $(\mathrm{mg} /$ $\mathrm{mm}^{2} / \mathrm{yr}$ ) of cast piston substrates in brake oil. The corrosion of cast $\mathrm{Al}$ alloy was characterized by different trends of corrosion rate occurring as increasing corrosion rate between 1 and 9 days of immersion, constant rate at 9-24 days, increasing rate at 24-34 days, constant rate at 34-51 days, followed by decreasing corrosion rate at 51 to 62 days, and finally increasing rate from 62 to 70 days. The cast $\mathrm{Al}$ alloy has the highest range of corrosion rate (0.030$0.033) \mathrm{mg} / \mathrm{mm}^{2} / \mathrm{yr}$ occurring for almost about 32-60 days. The best fit models were developed for the trend using MS excel application of linear equations relating the wear rate to time. The mathematical model equation is derived for the corrosion rate $R_{C}$ as in

$$
R_{C}=0.0002 x+0.0184,
$$

where $0 \leq x \leq 70, x$ is immersion time (days) and $R_{C}$ is the corrosion rates of the cast $\mathrm{Al}$ alloy with respect to immersion time in brake oil.

Figures 7(b) and 7(c) illustrate the trends of the solutions $\mathrm{pH}$ and the electrode potentials (EP) of the cast $\mathrm{Al}$ alloy immersed in brake oil for 70 days. The solution $\mathrm{pH}$ ranged between 6.5 and 8.7. This explained that the solution $\mathrm{pH}$ falls within the acidic range within the first 2 days of immersion. The chemical composition (Figure 7(b)) of the oil 


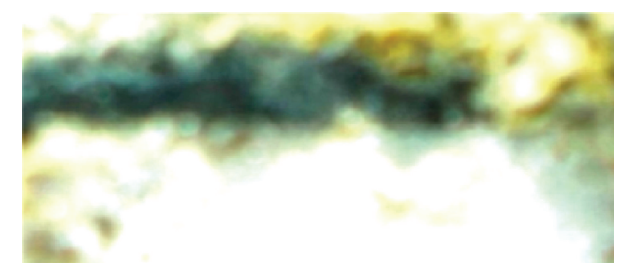

(a)

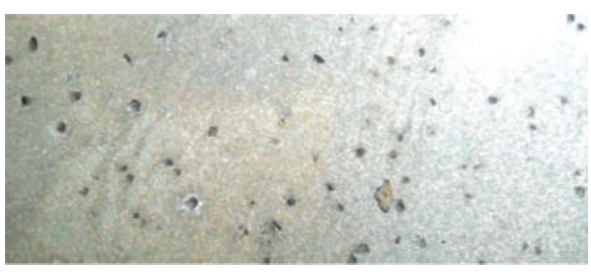

(b)

FIGURE 6: Microphotographs of corrosion of cast piston after 70 days.

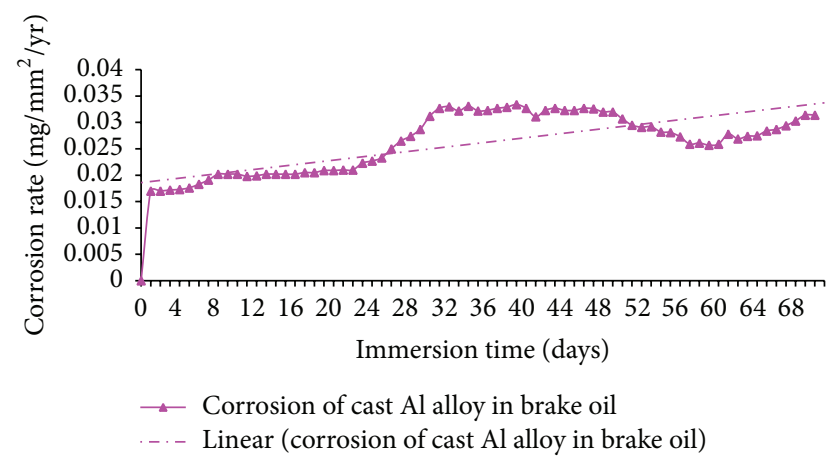

(a)

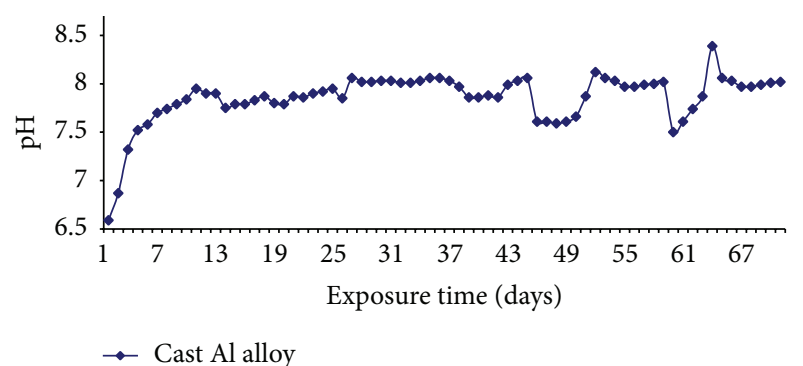

(b)

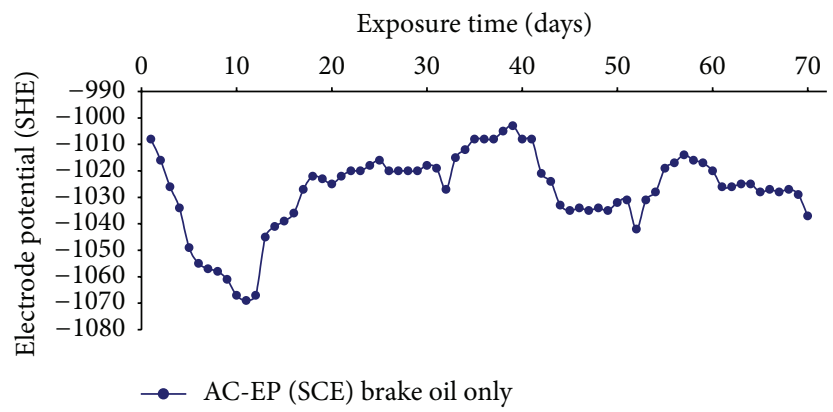

(c)

FiguRE 7: (a) Corrosion rate $\left(\mathrm{mg} / \mathrm{mm}^{2} / \mathrm{yr}\right.$ ) of cast piston substrates in brake oil. (b) $\mathrm{pH}$ of cast $\mathrm{Al}$ alloy substrates at various immersion times in brake oil. (c) Electrode potential (SHE) of cast Al alloy at various immersion times in brake oil.

media shows that it is water soluble and highly alkaline in nature. There has been the tendency of the fluid absorbing moisture from the atmosphere especially in case that the surface is exposed to air or not contained in an air tight vessel. The possible chemical reactions by the form and entrapped oxide compound within $\left(\mathrm{Al}_{2} \mathrm{Si}_{4} \mathrm{O}_{10}, \mathrm{MgO} \cdot \mathrm{Al}_{2} \mathrm{O}_{3}\right.$, and $\left.\mathrm{SiO}_{2}\right)$ and on the surface $\left(\mathrm{Al}_{2} \mathrm{O}_{3}\right)$ cause contaminations of the oil by the immersed cast $\mathrm{Al}$ alloy. The contamination reduced the $\mathrm{pH}$ of the oil and tends toward the acidic range at the early stage of immersion. The $\mathrm{pH}$ increased with the exposure time except at few points of constant $\mathrm{pH}$ and reduction in media $\mathrm{pH}$. The EP (SHE) measurement in Figure $7(\mathrm{c})$ shows the electrochemical characteristic of the cast $\mathrm{Al}$ alloy in the oil environments. Five different corrosion characteristic behaviours were demonstrated as follows: constant corrosion, reduced corrosion, increased corrosion, passivation and passivation film break, and unstable corrosion.
TABLE 4: SEM/EDX spectrum processing of corrosion product on affected area of cast $\mathrm{Al}$ alloy.

\begin{tabular}{lccccccccc}
\hline Element & $\mathrm{C}$ & $\mathrm{O}$ & $\mathrm{Mg}$ & $\mathrm{Fe}$ & $\mathrm{Al}$ & $\mathrm{Si}$ & $\mathrm{Cu}$ & $\mathrm{Mn}$ & Total \\
\hline Weight \% & 38.78 & 51.21 & 0.08 & 6.17 & 3.66 & 0.04 & 0.02 & 0.04 & 100
\end{tabular}

4.4. Microstructural Examination of the Scrap and Cast Piston Substrates. For the purpose of comparison, the microstructures of scrap and cast piston substrates studied using higher resolution metallurgical microscope with digital camera under $\times 800$ magnifications are shown in Figures 8 and 9. The controlled cast specimen contains more refined fine grains than the scrap specimen.

The results of the Scanning Electron Microscopy (SEM) and Energy Dispersive X-ray (EDX) data analyses of the corrosion of cast piston in brake oil are presented in Figures 10 and 11 and Tables 4 and 5, respectively. 


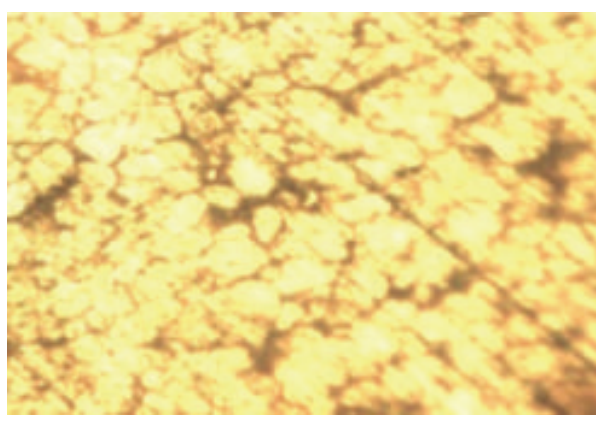

(a)

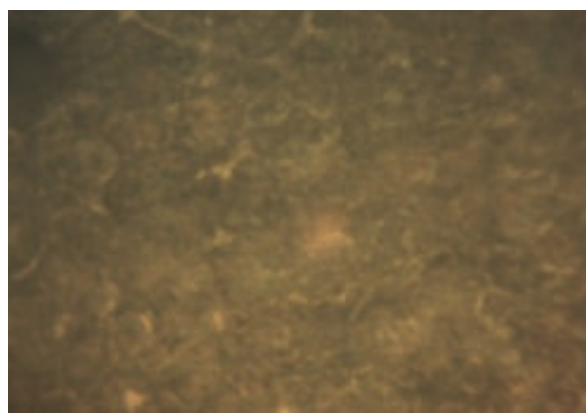

(b)

Figure 8: Microstructures of (a) scrap and (b) cast piston substrate sand cast using $80: 20$ mixing ratios at $750^{\circ} \mathrm{C}$ pouring temperature with magnesium ferrosilicon inoculants (magnification $\times 800$ ).

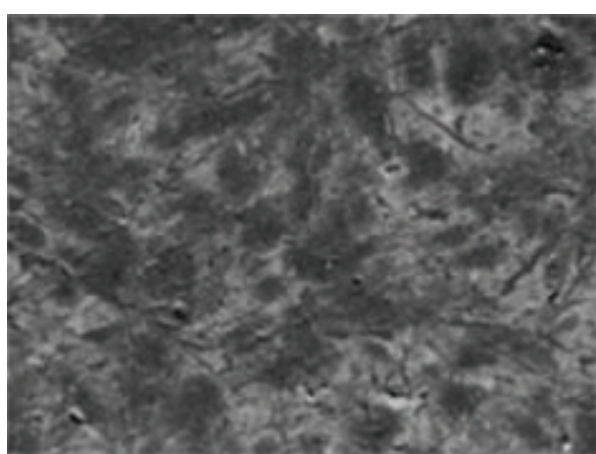

(a)

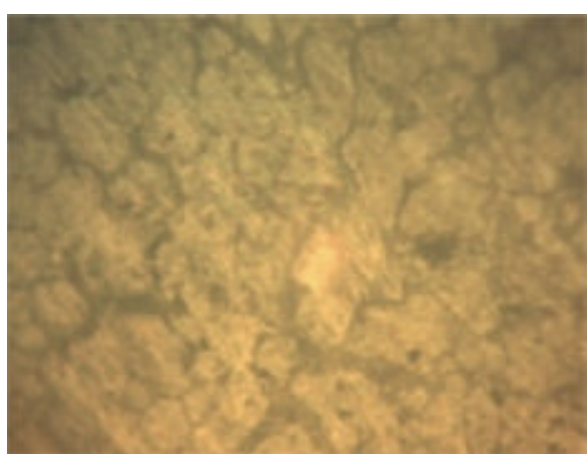

(b)

FIGURE 9: Nucleation (larger number of smaller grains) as identified in cast alloy piston (a, b) (magnification $\times 800$ ).

TABLE 5: SEM/EDX spectrum processing of corroded cast Al alloy substrate surfaces.

\begin{tabular}{lcccccccc}
\hline Element & $\mathrm{C}$ & $\mathrm{O}$ & $\mathrm{Mg}$ & $\mathrm{Al}$ & $\mathrm{Si}$ & $\mathrm{Cu}$ & $\mathrm{Fe}$ & Total \\
\hline Weight \% & 8.30 & 7.66 & 0.28 & 27.04 & 55.49 & 0.12 & 1.11 & 100 \\
\hline
\end{tabular}

Figures 10 and 11 are the SEM electron images of surfaces of cast $\mathrm{Al}$ alloy affected by corrosion. Tables 4 and 5 show the compositions of corrosion products and corroded surfaces of cast $\mathrm{Al}$ alloy substrates. There is clear revelation that there is oxidation of $\mathrm{Al}$ as presented by the SEM image and EDX data analysis. The study of $10 \mu \mathrm{m}$ size SEM image and EDX chemical characterisation in Figures 10(a) and 10(b) and Table 4 revealed that the selected portion is depleted of the metallic elements, as revealed in EDX spectral lines data. Figure 11 shows the $2 \mu \mathrm{m}$ size SEM images $(\mathrm{a}, \mathrm{b})$ of corroded cast $\mathrm{Al}$ alloy substrate surface immersed in oil.

Table 4 presents the compositions of corrosion products on corroded surfaces of cast Al alloy substrates. The EDX data shows that they contain about $38.78 \% \mathrm{C}, 51.21 \% \mathrm{O}, 0.08 \% \mathrm{Mg}$, $6.17 \% \mathrm{Fe}, 3.66 \% \mathrm{Al}, 0.04 \% \mathrm{Si}, 0.02 \% \mathrm{Cu}$, and $0.04 \% \mathrm{Mn}$. This validates the tendency of corrosion of cast aluminium alloy as a result of the interaction with the brake fluid.

The spectral analysis revealed that the selected area contains about $8.30 \% \mathrm{C}, 7.66 \% \mathrm{O}, 0.28 \% \mathrm{Mg}, 27.04 \% \mathrm{Al}$, $55.49 \% \mathrm{Si}, 0.12 \% \mathrm{Cu}$, and $1.11 \% \mathrm{Fe}$ as revealed in Table 5 .
The higher Si content as compared with $\mathrm{Al}$ indicates that the selected area contains some amount of $\mathrm{SiO}_{2}$ inclusion emanating from the sand casting process.

4.5. Wear and Corrosion of Cast Al Alloy Substrate in Brake Oil. Under the tribocorrosion condition, the synergistic constituent, $S_{(C, W)}$, is that part of the total damage that results from the interaction of material corrosion in fluid and the material wear processes. The total material loss, $T_{(C, W)}$, is related to the synergism by

$$
T_{(C, W)}=W_{0}+C_{0}+S_{(C, W)},
$$

where $T_{(C, M) C P}$ is the total material damage, $S_{(C, W)}$ is the synergetic constituent of the total material damage in fluid, $W_{0}$ is the mechanical wear without fluid, and $C_{0}$ is the damage due corrosion only which is measured electrochemically.

Since in the present reported work the corrosion and wear measurements were conducted in two settings, the condition for tribocorrosion cannot be used to interpret and in justifying the total damage rate and the concept of synergism. Thus by combining the results in Figures 4, 5, and 7 the behaviour of the $\mathrm{Al}$ alloy in the brake fluid subjected to wear and corrosion conducted under different set-up could be interpreted as in (14)-(17). The total constituent (total damage) resulting from the interaction of $\mathrm{Al}$ alloys corrosion 


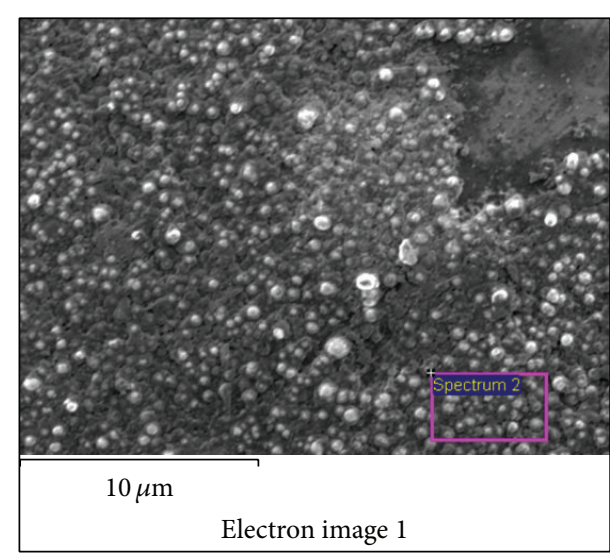

(a)

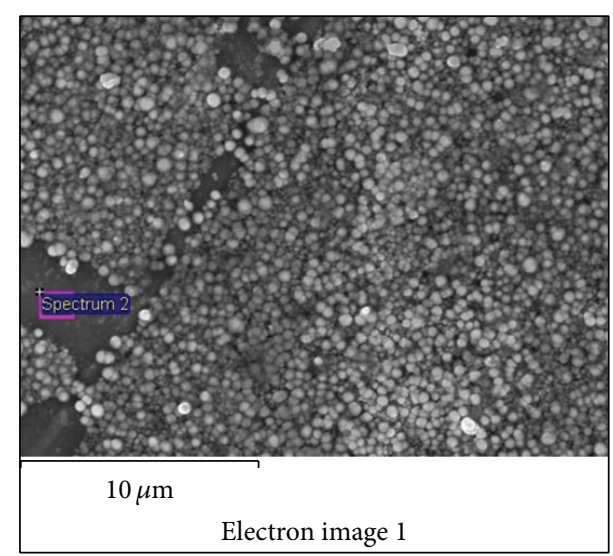

(b)

FIGURE 10: SEM showing images $(\mathrm{a}, \mathrm{b})$ of corrosion product on affected areas of cast $\mathrm{Al}$ alloy.

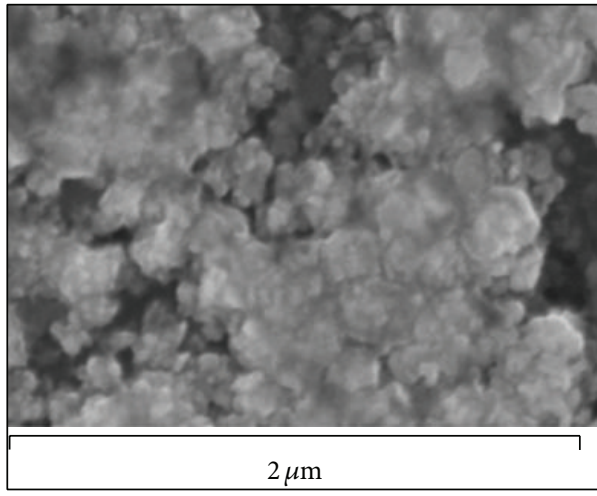

(a)

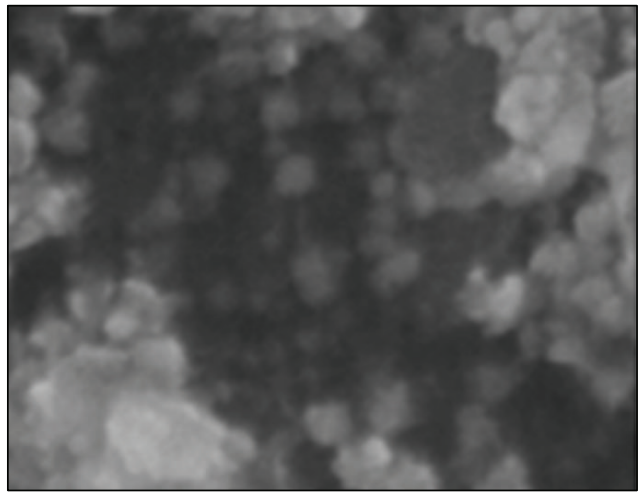

(b)

FIgURE 11: SEM images $(\mathrm{a}, \mathrm{b})$ of corroded cast $\mathrm{Al}$ alloy substrate surface immersed in oil.

and wear processes in brake oil is obtained from Figures 4, 5, and 7.

For a wet lubricating condition, the total material loss, $T_{(C, W)}$, is related to wear and corrosion by (16)-(17):

$$
\begin{aligned}
T_{(C, W) \mathrm{CP}} & =C_{0}+W_{(C, M)}, \\
W_{(o m) \mathrm{CP}} & =-6 E-09 x^{2}+2 E-07 x-1 E-07, \\
C_{o \mathrm{CP}} & =0.0002 x+0.0184,
\end{aligned}
$$

where $x$ is the exposure time (mins or days), $T_{(C, M) C P}$ is the total material damage due to corrosion and mechanical wear, $W_{(o m) \mathrm{CP}}$ is the mechanical wear damage measured in oil, and $C_{o \mathrm{CP}}$ is the corrosion damage for the cast $\mathrm{Al}$ alloy in oil.

Using (17), (18) and (19) are combined to get the total material loss rate $\left(T_{(C, W) C P}\right)$ in $\mathrm{g} / \mathrm{mm}^{2} / \mathrm{yr}$ for cast $\mathrm{Al}$ alloy in

$$
\begin{aligned}
T_{(C, W) C P}= & (5.48 E-07 x+5.04 E-05) \\
& +\left(-6 E-09 x^{2}+2 E-07 x-1 E-07\right),
\end{aligned}
$$

where $x$ is the exposure time (yr) and $T_{(C, M) C P}$ is the total material damage rate $\left(\mathrm{g} / \mathrm{mm}^{2} / \mathrm{yr}\right)$ due to corrosion and mechanical wear.

However for a dry nonlubricating condition, the total material loss, $T_{(C, W) C P}$, in (14) is related to mechanical wear only as expressed in

$$
T_{(C, W) C P}=W_{o C P},
$$

where $x$ is the exposure time ( $\mathrm{min}$ ) and $W_{0}$ is the wear damage of the $\mathrm{Al}$ alloy in the absence of oil or corrosion.

\section{Conclusions}

The extent of wear and corrosion of cast $\mathrm{Al}$ alloy used in brake oil has been studied and the following conclusions are drawn from the results obtained.

The wear and corrosion resistance of $\mathrm{Al}$ alloy material produced by sand casting from the combination of $80: 20$ sand ratio and $750 \pm 10^{\circ} \mathrm{C}$ pouring temperature was determined. The wear of cast piston surfaces occurs in the cylinder with oil and without oil. The addition of MgFeSi aids the precipitation of grain refining and strength enhancing compounds consisting of $\mathrm{Al}_{2} \mathrm{Si}_{4} \mathrm{O}_{10}, \mathrm{Al}_{15}(\mathrm{MnFe})_{3} \mathrm{Si}_{2}, \mathrm{Al}_{2} \mathrm{CuMg}$, 
and $\mathrm{Al}_{5} \mathrm{FeSi}$ and in conjunction with $\mathrm{CuAl}_{2}, \mathrm{MgO} \cdot \mathrm{Al}_{2} \mathrm{O}_{3}$, and $\mathrm{AlCu}$ phases in the eutectic $\mathrm{Al}-\mathrm{Si}$ structures. These give the cast piston higher hardness and strength values than what has been previously reported in the literature. The wear rate of cast $\mathrm{Al}$ alloy is higher without oil than in the cylinder with oil. For the wear tests with oil, the highest wear rate for cast $\mathrm{Al}$ alloy (CP) is $0.00000123 \mathrm{~g} / \mathrm{mm}^{2} / \mathrm{min}$ after 147000 wear cycles.

Corrosion still occurred despite the enhanced strength and hardness properties of the cast $\mathrm{Al}$ alloy. The sites of precipitation and entrapment of some of these compounds chiefly the oxides $\left(\mathrm{Al}_{2} \mathrm{Si}_{4} \mathrm{O}_{10}\right.$ and $\left.\mathrm{MgO} \cdot \mathrm{Al}_{2} \mathrm{O}_{3}\right)$ during casting and solidification of the cast Al-Si alloy serve as weak points for the corrosion attack. The corrosion tests yielded $0.0334 \mathrm{mg} / \mathrm{mm}^{2} / \mathrm{yr}$ as the highest corrosion rate within the 70 days of immersion in oil, a value considered being lower than what is obtained for corrosion of $\mathrm{Al}$ alloy in most common aqueous solution.

From these results, the cast $\mathrm{Al}$ alloy with the enhanced wear resistance property will perform better in oil, with few micrometre overlays of a more resistant metal or increased inhibitor content of the oil. Hence, the combination of material design (alloying) and coating will serve as better solution of repute in solving the wear and corrosion problems of the piston in the brake fluid.

\section{Conflict of Interests}

The authors declare that there is no conflict of interests regarding the publication of this paper.

\section{Acknowledgments}

The authors acknowledge the staff and management of the Premier Wings Engineering Services, Ado Ekiti, for providing the workshop services for the production and preparation of materials used for the study. The SEM/EDX analysis was performed at the Electrochemical \& Materials Characterization Research Laboratory of the Tshwane University of Technology, Pretoria, South Africa, and this is appreciated by the authors.

\section{References}

[1] K. C. Ludema, "Introduction to wear," in Friction, Lubrication, and Wear Technology, vol. 18 of The ASM Handbook, pp. 320628, 1992.

[2] S. Mischler and P. Ponthiaux, "A round robin on combined electrochemical and friction tests on alumina/stainless steel contacts in sulphuric acid," Wear, vol. 248, no. 1-2, pp. 211-225, 2001.

[3] S. Mischler and P. Ponthiaux, "Analytical solution for precessional magnetization switching in exchange biased high perpendicular anisotropy nanostructures," Journal of Physics D: Applied Physics, vol. 39, 7 pages, 2006.

[4] S. W. Watson, F. J. Friedersdorf, B. W. Madsen, and S. D. Cramer, "Methods of measuring wear-corrosion synergism," Wear, vol. 181-183, no. 2, pp. 476-484, 1995.

[5] Z. Abdel Hamid and M. T. Abou Elkhair, "Development of electroless nickel-phosphorous composite deposits for wear resistance of 6061 aluminum alloy," Materials Letters, vol. 57, no. 3, pp. 720-726, 2002.

[6] D. Landolt, "Electrochemical and materials aspects of tribocorrosion systems," in Corrosion and Surface Chemistry of Metals, pp. 227-274, EPFL Press, Lausanne, Switzerland, 2006.

[7] I. J. Polmear, Light Alloys: Metallurgy of the Light Metals, Butterworth-Heinemann, Arnold, Mo, USA, 1995.

[8] R. Bosch, Bosch Automotive Handbook, Bentley Publishers, Robert Bentley, Cambridge, Mass, USA, 7th edition, 2007.

[9] P. Marcus, "Introduction to the fundamentals of corrosion," in Corrosion: Fundamentals, Testing, and Protection, vol. 13 of ASM Handbook, pp. 3-4, ASM International, 2003.

[10] B. O. Adewuyi, "The influence of Fe variation on the corrosion behaviour of heat treated aluminium alloys in tomato juice," Nigerian Journal of Technology, vol. 21, no. 1, pp. 72-78, 2002.

[11] X. Sudarshan and M. K. Surappa, "Dry sliding wear of fly ash particle reinforced A356 Al composites," Wear, vol. 265, no. 34, pp. 349-360, 2008.

[12] D. Tabatabai, S. Szillies, F. Feil, G. Grundmeier, and W. Fürbeth, "Self-healing corrosion protective coatings for magnesium alloys by modifying anodizing layers with corrosion inhibitors," in Proceedings of the Eurocorr Abstracts, no. 4575, Stockholm, Sweden, September 2011.

[13] M. M. Khrushchov, "Principles of abrasive wear," Wear, vol. 28, pp. 69-88, 1974.

[14] H. Joseph, "Abrasive wear," in Friction, Lubrication, and Wear Technology, vol. 18 of The ASM Handbook, pp. 337-341, 1992.

[15] A. G. Evans, "Impact damage mechanics: solid projectiles," in Treatise on Materials Science and Technology, vol. 16, pp. 1-67, Academic Press, 1979.

[16] T. H. Kosel, "Solid particle erosion," in Friction, Lubrication, and Wear Technology, vol. 18 of The ASM Handbook, pp. 367-393, 1992.

[17] Y. Yan, Corrosion and tribo-corrosion behaviour of metallic orthopaedic implant materials [Ph.D. thesis], The University of Leeds, England, UK, 2006.

[18] S. Kuiry, Evaluation of Wear-Corrosion Synergythrough Tribocorrosion Studies, Bruker Nano Surfaces Division Tribology and Mechanical Testing, Campbell, Calif, USA, 2012, https:// www.bruker-axs.com/.

[19] A. Neville and T. Hodgkiess, "Characterisation of high-grade alloy behaviour in severe erosion-corrosion conditions," Wear, vol. 233-235, pp. 596-607, 1999.

[20] O. O. Ajibola, B. O. Adewuyi, and D. T. Oloruntoba, "Wear behaviour of sand cast eutectic Al-Si alloy in hydraulic brake fluid," International Journal of Innovation and Applied Studies, vol. 6, no. 3, pp. 420-430, 2014.

[21] O. O. Ajibola, D. T. Oloruntoba, and B. O. Adewuyi, "Metallurgical study of cast aluminium alloy used in hydraulic master brake calliper," International Journal of Innovation and Scientific Research, vol. 8, no. 2, pp. 324-333, 2014.

[22] O. O. Ajibola, D. T. Oloruntoba, and B. O. Adewuyi, "Design and performance evaluation of wear test jig for aluminium alloy substrate in hydraulic fluid," in Proceedings of the Corrosion Congress on Poster Presentation (Africorr '14), Pretoria, South Africa, July 2014.

[23] O. O. Ajibola, B. O. Adewuyi, and D. T. Oloruntoba, "Design and performance evaluation of wear test jig for aluminium alloy substrate in hydraulic fluid," in Proceedings of the 8th Engineering Forum, vol. 1, pp. 85-96, October 2012. 
[24] O. O. Ajibola and B. O. Jimoh, "Aluminium recycling industries in Nigeria: entrepreneurship challenges and opportunities," in Proceedings of the 7th Engineering Forum, vol. 2, pp. 238-247, Ado Ekiti, Nigeria, November 2011.

[25] O. O. Ajibola, D. T. Oloruntoba, and B. O. Adewuyi, "Effects of hard surface grinding and activation on electroless-nickel plating on cast aluminium alloy substrates," Journal of Coatings, vol. 2014, Article ID 841619, 10 pages, 2014.

[26] J. O. Alasoluyi, J. A. Omotoyinbo, J. O. Borode, S. O. O. Olusunle, and O. O. Adewoye, "Influence of secondary introduction of carbon and ferrosilicon on the microstructure of rotary furnace produced ductile iron," International Journal of Science and Technology, vol. 2, no. 2, pp. 211-217, 2013.

[27] ASTM International, ASTM Designation G 119-03: Standard Guide for Determining Synergism between Wear and Corrosion, ASTM International, West Conshohocken, Pa, USA, 2003.

[28] M. G. Fontana, Corrosion Engineering, McGraw-Hill, New York, NY, USA, 3rd edition, 1986. 

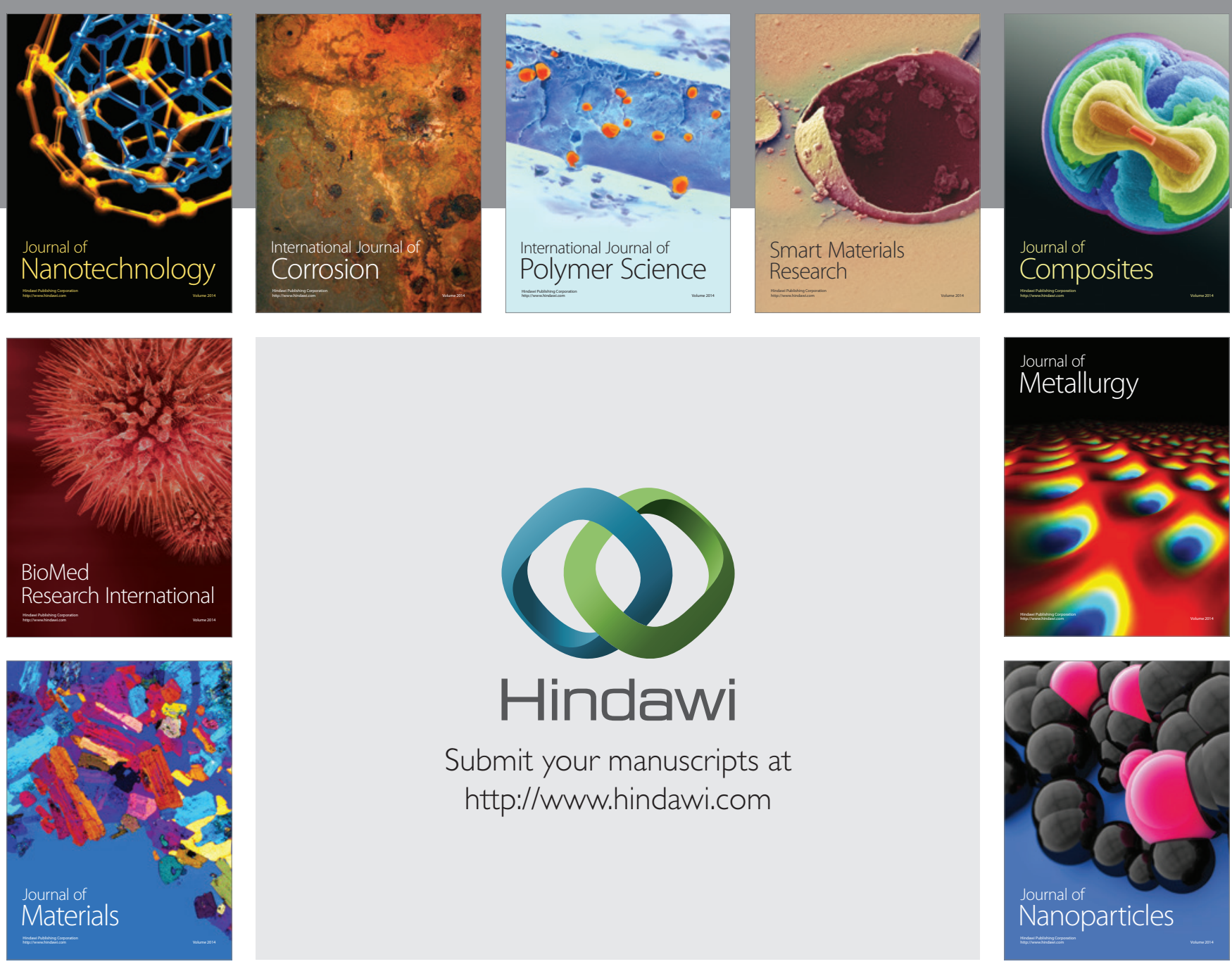

Submit your manuscripts at http://www.hindawi.com
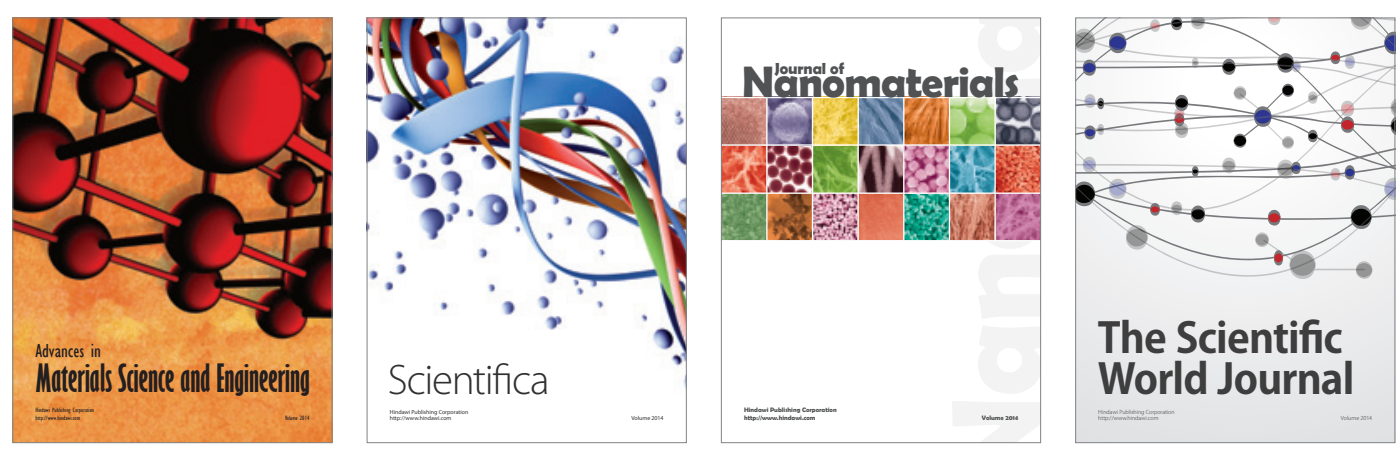

\section{The Scientific World Journal}
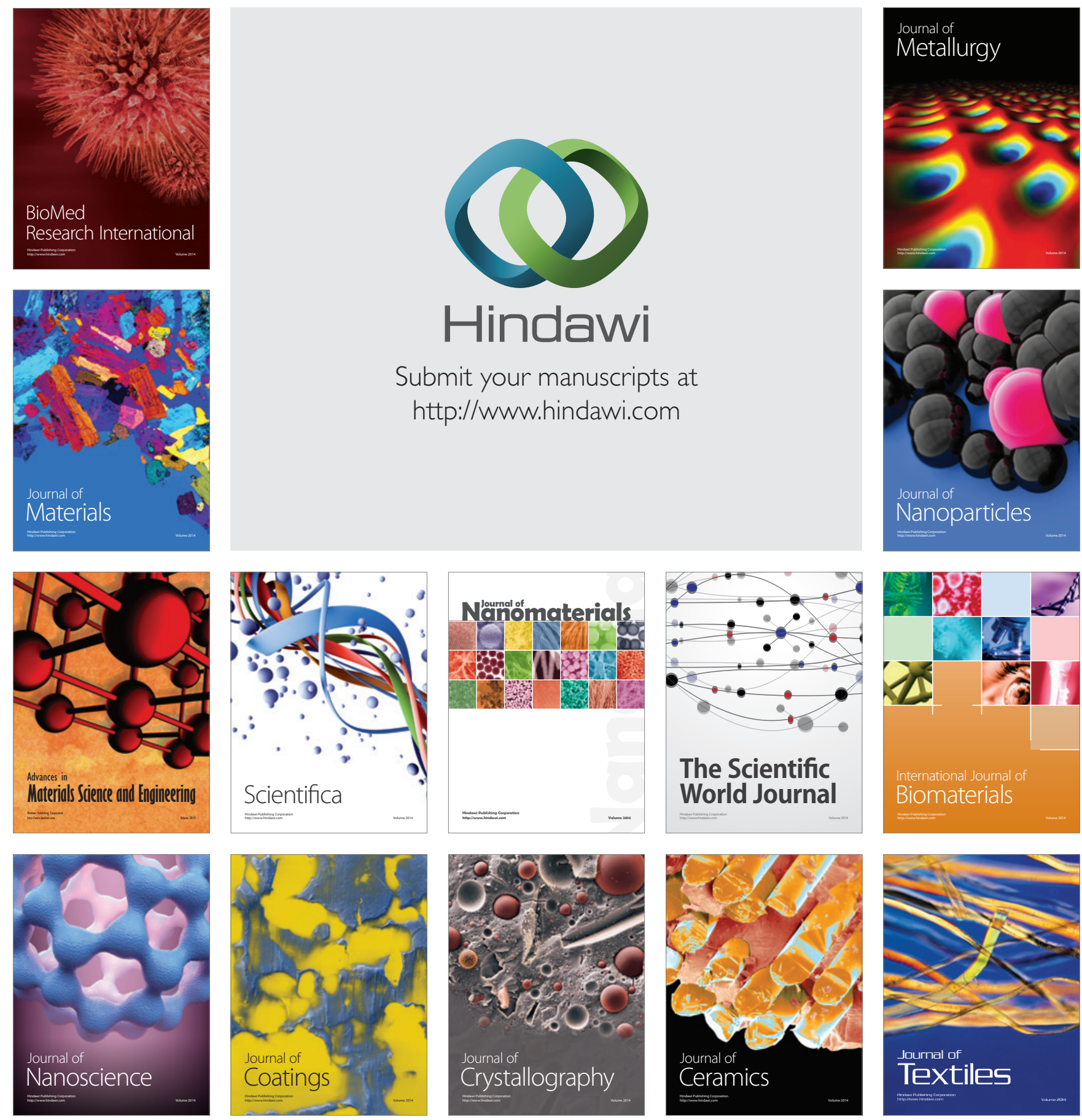